\title{
The Macro Economic Drivers of Non-Performing Loans (NPL): Evidence from Selected Countries with Heterogeneous Panel Analysis
}

\author{
Fatih AYHAN ${ }^{1}$ \& Mustafa Tevfik KARTAL ${ }^{2}$
}

\begin{abstract}
NPL could be treated as a critical issue in the financial systems of countries of which have bank-based infrastructures since NPL restrict the credit providing capacity of banks. Hence, necessary financing sources for economic growth and development could not be provided. In this context, the study aims to research the drivers of NPL in selected 23 countries. 4 independent drivers and yearly data between 2006 and 2018 are analyzed by using heterogeneous panel analysis. The empirical findings reveal that (i) credits, gross domestic products (GDP), and savings have statistically significant negative effect whereas foreign exchange rates (FER) have a statistically insignificant positive effect on NPL for the overall panel; (ii) $1 \%$ increase in credits reduces NPL by approximately 2\%; (iii); FER have statistically significant effects in some countries at the country base; (iv) negative coefficients for credits, savings, and GDP are consistent in both overall panel and country base.
\end{abstract}

Key Words: Non-Performing Loans; NPL-Drivers; Heterogeneous Panel

Takipteki Kredilerin Makroekonomik Belirleyicileri: Heterojen Panel Analizi Ile Seçilmiş Ülkelerden Elde Edilen Kanitlar

$\ddot{O} z$

Takipteki Krediler (NPL), bankaların kredi sağlama kapasitesini kısıtladığından, banka tabanlı altyapısı olan ülkelerin finansal sistemlerinde kritik bir konu olarak ele alınabilmektedir. Dolayısıyla bu durum ekonomik büyüme ve kalkınma için gerekli finansman kaynaklarının sağlanamamasına neden olmaktadır. Bu bağlamda, çalışma seçilmiş 23 ülkede NPL'nin belirleyicilerini araştırmayı amaçlamaktadır. 4 bağımsız belirleyici 2006-2018 arasındaki yıllık verileri ile heterojen panel analizi kullanılarak analiz edilmiştir. Ampirik bulgular, (i) krediler, gayri safi yurtiçi hasıla (GSYH) ve tasarrufların istatistiksel olarak anlamlı negatif etkiye sahip olduğunu, buna karşılık döviz kurlarının (FER) NPL üzerinde istatistiksel olarak anlamlı olmayan pozitif bir etkiye sahip olduğunu ortaya koymaktadır; (ii) Kredilerdeki \% 1'lik artış NPL'yi yaklaşık \% 2 oranında azaltmakta; (iii); FER'in bazı ülkelerde ülke bazında istatistiksel olarak önemli etkileri vardır; (iv) krediler, tasarruflar ve GSYİH için negatif katsayılar hem genel panel hem de ülke bazında tutarlidir.

Anabtar Kelimeler: Takipteki Krediler, NPL; NPL'nin Belirleyicileri; Heterojen Panel Analiz

Atıf İçin / Please Cite As:

Ayhan, F. \& Kartal, M. T. (2021). The macro economic drivers of non-performing loans (NPL): Evidence from selected countries with heterogeneous panel analysis. Manas Sosyal Arastırmalar Dergisi, 10(2), 986-999.

Geliş Tarihi / Received Date: 27.09.2020

Kabul Tarihi / Accepted Date: 10.01.2021

\footnotetext{
${ }^{1}$ Corresponding Author, Assoc. Prof. Dr. - Bandırma Onyedi Eylül University, Faculty of Economics And Administrative Sciences, Department of Economics, Balıkesir/Turkey, fayhan@bandirma.edu.tr

(iD ORCID: 0000-0002-7447-5506

2 Assoc. Prof. - Strategic Planning and Investor Relations Directorate in Borsa Istanbul, Istanbul/Turkey, mustafatevfikkartal@gmail.com,

(iD ORCID: 0000-0001-8038-8241
} 


\section{Introduction}

Financial systems are mainly divided into two groups which are either bank-based or market-based (Kartal, İbiş, \& Çatıkkaş, 2018). The type of financial system has a key role because infrastructure and financial institutions are designed accordingly. Also, financial intermediaries in these systems have a significant role in the development of countries since economic activities are funded by financial institutions using money and credit channels. When examining the economies of countries, it can be seen that they generally have bank-based financial systems.

The banks are the main financial intermediaries in bank-based financial systems. Firstly, banks collect deposits from those who have a cash surplus and want to save. Secondly, banks provide credits to whom which they need borrowing money to perform economic activities such as investments and consumption. Hence, banks manage long-term assets and short-term liabilities, transform maturities, and finance their risky assets (including illiquid assets like NPL) as well (Saunders \& Cornett, 2006, p. 295; Distinguin, Roulet, \& Tarazi, 2013, p. 3295; Mohammad, Asutay, Dixon, \& Platonova, 2020, p. 2). In this pattern, credits are the main financial instruments.

As financial institutions providing a large volume of credits, returns (repayment) of credits are quite vital for the sustainability of banks. At this point, NPL is the main issue. NPL could be defined generally as unfavorable credits past due 90 days (Erdaş, 2019, p.372; Kilıç Depren \& Kartal, 2020, p. 736). Credit allocation capacity, profitability, and liquidity of banks decrease when NPL increase and vice versa. Also, NPL takes place among the main indicators that reflect the soundness of banks and the banking sector (Touny \& Shehab, 2015, p. 11). Therefore, the management of banks desires to have low-level NPL to sustain credit growth while economy management would like to stimulate economic growth via credit growth in turn (Barseghyan, 2010, p. 874). Countries, which have bank-based financial systems, should focus on banking related issues to stimulate economic activities (Kaufmann \& Valderrama, 2008, p. 267).

The stability and soundness of banking sectors have importance for economic development and growth of all countries, however, especially for emerging countries since they desire to be among developed countries. One of the main necessities is to achieving and sustain stability in macroeconomic and financial indicators for this aim. However, this is not easy in a globalizing world. This phenomenon makes all countries interdependent. In such a context, macroeconomic and financial indicators are affected by a variety of indicators including global and national. While national indicators (e.g. credits, savings, GDP) are fully or mostly under the control of countries, unfortunately, global factors (e.g. FER) are not under the control of countries. Nevertheless, countries can affect and direct the effects of global factors.

NPL could affect the development of countries with affecting credit growth, economic growth, and others such as FER, inflation, and unemployment by causing uncertainty. Sudden increases in NPL may cause negative effects, a high amount of bankruptcies, the decrease in the allocation of new credits, and hence may result in destructive developments in economies, respectively. Therefore, the amount and level of NPL cause divergence from the development and growth path (Bilgin, Gözgör, Lau, \& Sheng, 2018, p. 2; Gözgör, Demir, Belás, \& Yeşilyurt, 2019, p. 2).

While market-based financial systems are at the forefront in developed countries mostly, on the other hand, financial systems of emerging countries rely on mainly banks. Credits are the main and most important financial instruments in such countries. Therefore, the sustainability of credit growth by ensuring a low amount and level of NPL is quite critical. Credit growth is much related to the soundness and financial stability of banks and the banking sector and deteriorations in credits are seen as NPL. Besides, a deep relationship between credits, NPL, and macroeconomics and financial indicators exists. When deteriorations increase in bank-based economies, NPL also increases at the same time.

As understand from the explanations above, credits, and NPL in particular, are important. While NPL has been increasing in some countries like Argentina, Colombia, Fiji, Kenya, Ukraine, and Turkey recently, on the other hand, some of the other countries benefit from the low-level NPL like El Salvador, Germany, and Indonesia or the decreasing NPL like Croatia, Gambia, Ireland, Italy, Malta, Pakistan, and Spain (World Bank (WB) Open Data Database, 2020). Although emerging countries cannot stand the negative development in the banking sector and on the economy as a whole resulting from NPL, this does not mean that developed countries can stand. NPL are significant for both developed and emerging 
countries as well. Therefore, all countries should keep NPL under control and make NPL stable at an ideal level. Otherwise, NPL may increase the default probability of banks and could result in bankruptcies which cause a decrease in credit providing to economic actors and the decreasing in economic growth in turn. Hence, a vicious circle occurs between NPL and negativities (Morgan \& Pontines, 2018, p. 111).

Multiple factors should be considered to manage NPL effectively and success at a low-level because NPL various indicators may be effective (Dimitrios, Helen, \& Mike, 2016, p.116). Therefore, firstly the factors, which affect NPL, and their effects, which either positive or negative on NPL, should be determined. Secondly, countries should develop and apply policies to decrease the negative effects and increase the positive effects of factors on NPL by considering the results of the analysis (Zeng, 2012, p. 101).

The study aims to contribute to the literature by examining the drivers of NPL in selected countries by using the most recent data. 23 countries are selected to be taken into account in the study by considering data availability. In this context, 4 main independent drivers, yearly data for the period between 2006 and 2018, and the heterogeneous panel analysis are used in the study to define the drivers of NPL in the selected countries. Focusing on a large sampling of countries (23) and using a large data set (13 years) from 2006 to 2018, which is the most recent data, is the main contribution of the study. Also, the study defines that credits, GDP, and savings have a statistically significant negative effect whereas FER have statistically insignificant positive effect on NPL for the overall panel. Also, it is defined that FER have statistically significant negative and positive effects in some countries Moreover, negative coefficients for credits, savings, and GDP variables are consistent in both the overall panel and country base. The results prove the importance of macroeconomic determinants on NPL.

This study includes 5 parts. Part 2 presents the literature review. Part 3 summarizes the variables, data, scope, and methodology used in the study. Part 4 shows the empirical results of heterogeneous panel analysis. Part 5 presents a discussion and conclusion.

\section{Literature Review}

The literature includes a variety of studies regarding NPL. These studies research the relationship between NPL and different macroeconomic and financial variables like credits, FER, economic growth.

Credits are one of the important indicators affecting NPL for all countries. Studies (Das \& Ghosh, 2007, p. 10; Boudriga, Taktak, \& Jellouli, 2010, p. 10; Saba, Kouser, \& Azeem, 2012. p. 147; Jakubik \& Reininger, 2013, p. 56; Ghosh, 2015, p.102; Konstantakis, Michaelides, \& Vouldis, 2016, p. 160; Killç Depren \& Kartal, 2020, p. 1) research the effects of domestic credit growth on NPL in countries (India, Middle East \& North Africa (MENA) countries, USA, CESEE countries (Bulgaria, Croatia, the Czech Republic, Hungary, Poland, Romania, Russia, Slovakia, and Ukraine), USA, Greece, Turkey), respectively. A positive relationship between credit growth and NPL is found in these studies. On the other hand, Vithessonthi (2016, p. 299) determines a negative nexus between credit growth and NPL. By taking into consideration the studies, a positive or a negative effect of credits is expected on NPL. Domestic credit to the private sector (\% of GDP) is considered as determinant because most of the credits are provided to domestics and the share of credits in GDPS could be meaningful when analyzing the effects of credits on NPL.

FER is much related to NPL. A variety of studies (Farhan, Sattar, Chaudhry, \& Khalil, 2012, p. 96; De Bock \& Demyanets, 2012, p. 22; Beck, Jakubik, \& Piloui, 2013, p. 20; Jakubik \& Reininger, 2013, p. 57; Tanaskovic \& Jandric, 2015, p. 58; Umar \& Sun, 2018, p. 282; Kulıç Depren \& Kartal, 2020, p. 736) research the effects of FER on NPL in various countries (Pakistan, selected emerging and advanced countries, CESEE countries, Central, Eastern and South Western European Countries (Albania, Bosnia and Herzegovina, Bulgaria, Croatia, Hungary, Lithuania, Montenegro, Macedonia, Romania, Serbia, and Slovenia), China, Turkey), respectively. A positive relationship between FER and NPL is found generally in these studies. On the other hand, Buncic \& Melecky (2013, p. 354) and Klein (2013, p. 11) determine that FER does not affect NPL in selected 54 high and middle-income countries. By taking into account these studies, a positive effect of FER is expected on NPL. The official exchange rate (LCU per USA Dollar, period average) is selected as determinant because USD is the most FER used in the world.

Economic (GDP) growth is another indicator that could be influential on NPL. There are some studies which examine the nexus between NPL and economic growth in Spain, 6 Arabian countries, selected emerging \& advanced countries, USA, Italy, CESEE countries, China, and Turkey by Salas and 
Saurina (2002, p. 215); Espinoza and Prasad (2010, p. 13); De Bock and Demyanets (2012, p. 14); Beck et al. (2013, p. 17); Jakubik and Reininger (2013, p. 56); Messai and Jouini (2013, p. 856); Skarica (2014, p. 52); Umar and Sun (2018, p. 282); Kilıç Depren and Kartal (2020, p. 1). These studies conclude that NPL has a negative relationship with economic growth. In other words, NPL decrease when economic growth increases or vice versa. By considering these studies, a negative effect of economic growth on NPL is expected. Annual GDP growth (\%) is selected as a determinant since these figures show the growth in the annual base.

Besides drivers taking place above, as authors, we thought that savings could affect NPL. The effect of savings on NPL is expected as negative. Because while savings increase, NPL is expected to decrease since savings could be used to pay credits.

When evaluating studies overall, it can be generally summarized that NPL is much related to macro indicators, development of macroeconomic indicators affect NPL, and improvement in macroeconomic indicators reduces NPL (Louzis, Vouldis, \& Metaxas, 2012, p. 1020; Nkusu, 2011, p. 13; Konstantakis et al., 2016, p. 159). Also, the studies examine the changes in NPL by using different determinants. Moreover, various statistical and econometric methods like cointegration, generalized method of moments, Granger causality test, regression, vector error correction model are used in these studies.

\section{Data, Variables, Scope, and Methodology}

\section{Data and Variables}

Data for dependent and all independent variables have been obtained from WB Open Data Database (2020). In the study, the share of NPL (nonperforming loans to total gross loans) of banks is selected as a dependent variable by following the studies of Dimitrios et al. (2016, p.216), Alandejani \& Asutay (2017, p.842), and Kiliç Depren \& Kartal (2020, p.736). Annex-1 shows the NPL figures for countries examined in the study.

Besides, 23 countries, 4 drivers, yearly data for the period of 2006-2018, and heterogeneous panel analysis are used to determine the drivers of NPL. Although many more countries and a long period were expected to be included in the study, data for some countries, variables, and years have not been published in WB Database. By considering the data availability, the scope of the study is restricted to 23 countries and 4 independent drivers. Table 1 summarizes the independent drivers used in the study which are determined by benefiting literature review.

Table 1. Independent V ariables

\begin{tabular}{llll}
\hline \multicolumn{1}{c}{ Variables } & \multicolumn{1}{c}{ Symbol } & \multicolumn{1}{c}{ Description } & Expected Effects \\
\hline Credits & CREDIT & Domestic credit to private sector (\% of GDP) &,+- \\
FER & FER & Official exchange rate (LCU per USA Dollar, period average) & + \\
GDP Growth & GRWTH & Annual GDP growth (\%) & - \\
Savings & SAVING & Gross savings (\% of GDP) & - \\
\hline
\end{tabular}

Positive (+) effect means that NPL increases when independent variables increase.

Negative (-) effect means that NPL decreases when independent variables increase.

In the study, 23 countries are selected to be examined by considering data availability. Table 2 summarizes countries included in the study.

Table 2. Selected Countries and Their Codes

\begin{tabular}{llll}
\hline Country & Country Code & Country & Country Code \\
\hline Argentina & ARG & Indonesia & IDN \\
Armenia & ARM & Ireland & IRL \\
Australia & AUS & Italy & ITA \\
Austria & AUT & Madagascar & MDG \\
Belgium & BEL & Malta & MLT \\
Bosnia and Herzegovina & BIH & Mexico & MEX \\
Brazil & BRA & North Macedonia & MKD \\
Chile & CHL & Spain & ESP \\
Colombia & COL & Thailand & THA \\
Croatia & HRV & Turkey & TUR \\
Germany & DEU & Ukraine & UKR \\
Honduras & HND & & \\
\hline
\end{tabular}




\section{Methodology}

\section{Panel Data Analysis}

Having information about the stationarity of variables is important to reach reliable findings in panel data analysis, similar to time series analysis. On the contrary to time series analysis, the correlation or cross-sectional dependence and slope homogeneity are important terms to be tested during the panel data analysis.

There are first and second-generation panel unit root tests to be investigated the interaction between the cross-sections. First-generation panel root unit root tests don't take into consideration the crosssectional dependence while the second-generation panel unit root tests take into consideration this problem. Because of the first generation panel unit root tests' deficiency, their results cause unreliable findings after panel analysis.

Baltagi, Feng, and Kao (2012, p. 168) revealed that traditional $t$ and $F$ tests became invalid and caused inconsistent results when there is a cross-sectional dependence in the model. Thus, the analysis starts to test the existence of cross-sectional dependence and then keep on choosing the appropriate panel unit root tests. Slope homogeneity is the other important term for panel data analysis and this term shows that all cross-sections that constitute the panel have unique and statistically significant.

Maddala, Trost, Li, and Joutz (1997, p. 90) found that heterogeneous panels caused heterogeneity bias indeed these panels were homogenous. Thus, the correlation between the cross-sections and slope homogeneity must be detected and appropriate panel unit root tests and estimators must be selected following the results.

\section{Cross-Section Dependency (CD) Test}

Pesaran (2004, p. 5) suggests a cross-sectional dependence test for heterogeneous slope or panels with larger $\mathrm{N}$ (cross-section) than $\mathrm{T}$ (time) and panels with unit-roots. Pesaran (2004, p.5) CD test statistics where the null hypothesis is $H_{0}: \rho_{i j}=0$, is estimated as follows in Eq.1:

$$
C D=\sqrt{\frac{2 T}{N(N-1)}\left(\sum_{i=1}^{N-1} \sum_{j=i+1}^{N} \hat{\rho}_{i j}\right)}
$$

In Eq.1, $\rho_{i j}: i, j$ shows the residual's correlation coefficient and calculated as follows in Eq.2:

$$
\left.\hat{\rho}_{i j}=\sum_{t=1}^{T} e_{i t} e_{j t} /\left(\sum_{t=1}^{T} e_{i t}^{2}\right)^{1 / 2} \sum_{t=1}^{T} e_{j t}^{2}\right)^{1 / 2}
$$

$e_{i t}$ residuals for the Ordinary Least Squares (OLS) in Eq.2. Monte Carlo simulations claim that Pesaran (2004,p.5) CD test shows better performance than the Breusch-Pagan (1980, p.239) LM test in the case of short panels that include larger N and smaller T (Baltagi, 2008, p.62).

\section{CIPS Panel Unit Root Test}

CIPS Panel unit root test proposed by Pesaran (2007, p.284) is based on modeling the cross-sectional dependence via factors. Pesaran (2007, p.276) extended the Augmented Dickey-Fuller (ADF) regression with cross-sectional means and lagged series and proposed that correlation between the cross-sections may be eliminated by taking the first difference of the concerning regression. The CIPS statistics is the mean of CADF statistics obtained by extended ADF's and calculated as follows in Eq. 3:

$$
\operatorname{CIPS}(N, T)=N^{-1} \sum_{t=1}^{N} t_{i}(N, T)
$$

The truncated version of CIPS statistics is shown as in Eq.4:

$$
\operatorname{CIPS}^{*}(N, T)=N^{-1} \sum_{i=1}^{N} t_{i}^{*}(N, T)
$$


The strength of the CIPS test is can be stated that it displays better performance even if in small samples (Pesaran, 2007, p.268).

\section{Parameter Homogeneity and Swamy $\widehat{\boldsymbol{S}}$ Test}

A slope homogeneity test for the panel is developed by Swamy (1970, p. 311). Swamy (1970, p. 322) neglect each panel-specific structure of a panel dataset, analyzed each section via OLS, and then found out the difference between the fixed effects estimator to test the random-effects model (RCM). It is concluded that a panel data analysis performed by ignoring the possible heterogeneity of the regression coefficient vector in a model might lead to biased estimates.

The null hypothesis of Swamy's slope homogeneity test is indicated as $H_{0}: \beta_{i}=\beta$ and $\beta_{i}$ shows that the coefficient vectors are constant and they are also homogeneous. The test statistics are shown in Eq. 5:

$$
\hat{S}=X_{k(N-1)}^{2}=\sum_{i=1}^{N}\left(\hat{\beta}_{i}-\bar{\beta}^{*}\right)^{\prime} \hat{V}_{i}^{-1}\left(\hat{\beta}_{i}-\bar{\beta}^{*}\right)
$$

$\hat{\beta}_{i}$ indicates the OLS estimators derived from the regressions to the cross-sections, $\bar{\beta}^{*}$ Weighted fixed effects (WE) estimator, and $\widehat{V}_{i}$ indicates the variance difference of these estimators in Eq.5, (Pesaran \& Yamagata, 2008, p. 63).

\section{Augmented Mean Group (AMG) Estimator}

Eberhardt and Bond (2009, p. 1), and Eberhardt and Teal (2010, p. 14) developed an estimator to use for the panel data set which based on the assumption of cross-section correlations and slope heterogeneity. Simply, the model is based on the Mean group estimator as follows in Eq. 6:

$$
\Delta y_{i t}=b^{\prime} \Delta x_{i t}+\sum_{t=2}^{T} c_{t} \Delta D_{t}+e_{i t}=\widehat{c_{t}} \equiv \hat{\mu}_{t}^{*}
$$

The first difference is expanded with the first differences in pooled regression (T-1) times with time dummy variables and coefficients are estimated as follows in Eq. 7:

$$
y_{i t}=a_{i}+b_{i}^{\prime} x_{i t}+c_{i t}+d_{i} \hat{\mu}_{t}^{*}+e_{i t}
$$

$\hat{\mu}_{t}^{*}$, takes place in the regression of each cross-section, and models are estimated as Eq. 8:

$$
\hat{b}_{A M G}=N^{-1} \sum_{i} \hat{b}_{i}
$$

Finally, the AMG estimator combines with Pesaran \& Smith (1995, p.79)'s mean group technique. Eberhardt \& Bond (2009, p.19) applied Monte Carlo simulations and they found out that this estimator works quite well, especially in heterogeneous macro panels that correlated between cross-sections (Eberhardt \& Bond, 2009, p.19).

\section{Empirical Results}

The open form of the model used in this study is as in Eq. 9:

$$
N P L_{i t}=\alpha_{0 i}+\beta_{1 i} C R E D I T_{i t}+\beta_{2 i} \operatorname{SAVING}_{i t}+\beta_{3 i} G D P_{i t}+\beta_{4 i} F E R_{i t}+\varepsilon_{i t}
$$

Table 3 indicates the descriptive statistics about the variables evaluated in the study. According to descriptive statistics, the panel data set has the characteristics of being a balanced and short $(N>T)$ panel.

Table 3. Descriptive Statistics

\begin{tabular}{llllllll}
\hline Variables & $\begin{array}{l}\text { Cross-Sections } \\
(\mathbf{N})\end{array}$ & Time $(\mathbf{T})$ & Obs. & Mean & St. Dev. & Min. & Max. \\
& 23 & 13 & 299 & 6.050801 & 7.281061 & 0.53 & 59.76 \\
NPL & 23 & 13 & 299 & 68.49699 & 38.44034 & 8.78 & 173.98 \\
CREDIT & 23 & 13 & 299 & 21.15663 & 6.0267 & 5.46 & 36.62 \\
SAVING & 23 & 13 & 299 & 2.726603 & 3.689504 & -14.76 & 25.16 \\
GDP & 23 & 13 & 299 & 698.0978 & 2274.351 & 0.68 & 14236.94 \\
FER & & & & & & \\
\hline
\end{tabular}


AYHAN \& KARTAL

The Macro Economic Drivers of Non-Performing Loans (NPL): Evidence from Selected Countries with Heterogeneous Panel Analysis

Table 3 shows the results of the cross-sectional correlation test for the variables analyzed. The null hypothesis, which states that there is no correlation between cross-sections, is rejected in all variables. For this reason, the analysis goes on the second generation panel unit root tests that take into account the cross-section problem.

Table 4. Pesaran CD Test Results

\begin{tabular}{lll}
\hline Variables & CD Test Statistics & Probability \\
\hline NPL & 4.78 & $0.000^{*}$ \\
CREDIT & 5.25 & $0.000^{*}$ \\
SAVING & 7.31 & $0.000^{*}$ \\
GDP & 30.17 & $0.000^{*}$ \\
FER & 8.91 & $0.000^{*}$ \\
\hline Note: ${ }^{* *},{ }^{* *}$ denote the significance levels of alpha at $0.01,0.05$, and 0.10 respectively. &
\end{tabular}

Table 5. CIPS Panel Unit Root Test Results

\begin{tabular}{lll}
\hline Variables & Intercept & Intercept and Trend \\
\hline NPL & $-2.160^{* * *}$ & $-2.610^{* * *}$ \\
CREDIT & -1.318 & -2.395 \\
$\Delta$ CREDIT & $-3.089^{*}$ & $-3.356^{*}$ \\
SAVING & -1.315 & -2.318 \\
$\Delta$ SAVING & $-3.151^{*}$ & $-3.073^{*}$ \\
GDP & $-2.396^{*}$ & $-2.678^{* * *}$ \\
FER & -1.227 & -1.495 \\
$\Delta$ FER & $-2.228^{* *}$ & $-2.593^{* * *}$ \\
\hline
\end{tabular}

Note: *, **, *** denote the significance levels of alpha at $0.01,0.05$, and 0.10 respectively.

Table 5 displays the results of the CIPS test to investigate the existence of the unit root in the variables. According to these results, NPL and GDP are stationary at the level; in other words, I(0) and CREDIT, SAVING and FER are stationary at first difference level which means I(1).

Table 6. Swamy Slope Homogeneity Test Results

\begin{tabular}{lc}
\hline$\chi^{2}$ Statistics & 1623.01 \\
$\chi^{2}$ Probability & $0.0000^{*}$ \\
\hline Note: ${ }^{*}, * * * *$ denote the significance levels of alpha at $0.01,0.05$, and 0.10 respectively.
\end{tabular}

Table 7. Pesaran Cross-Sectional Dependence Test Results

\begin{tabular}{lc} 
CD Test Statistics & 2.10 \\
Prob. & $0.036^{* *}$ \\
\hline Note: $* * *, * * *$ denote the signifficance levels of alpha at $0.01,0.05$, and 0.10 respectively.
\end{tabular}

Before estimating the model, it is necessary to test whether the model in Eq. 9 has slope homogeneity and cross-sectional correlation problem and then choose an estimator appropriate for the results. Table 6 and Table 7 show the slope homogeneity and inter-unit correlation test results of the model in the Eq. 9. According to the Swamy test, the null hypothesis that the slopes are homogeneous is rejected and we admit that the slopes are heterogeneous.

According to Pesaran (2004, p. 1) CD test result, the null hypothesis that there is no correlation between cross-sections in the model is rejected. Thus we can admit that there is a correlation problem between the cross-sections in the model.

These results indicate that the estimator to be selected to forecast the panel regression model should have slope heterogeneity and cross-sectional dependence. Therefore, to estimate the panel regression model, the AMG estimator for Eberhardt and Bond (2009) and Eberhardt and Teal (2010) Tests, which can effectively work under two necessary assumptions, is preferred. 
Table 8. AMG Estimation Results for Panel Regression Model

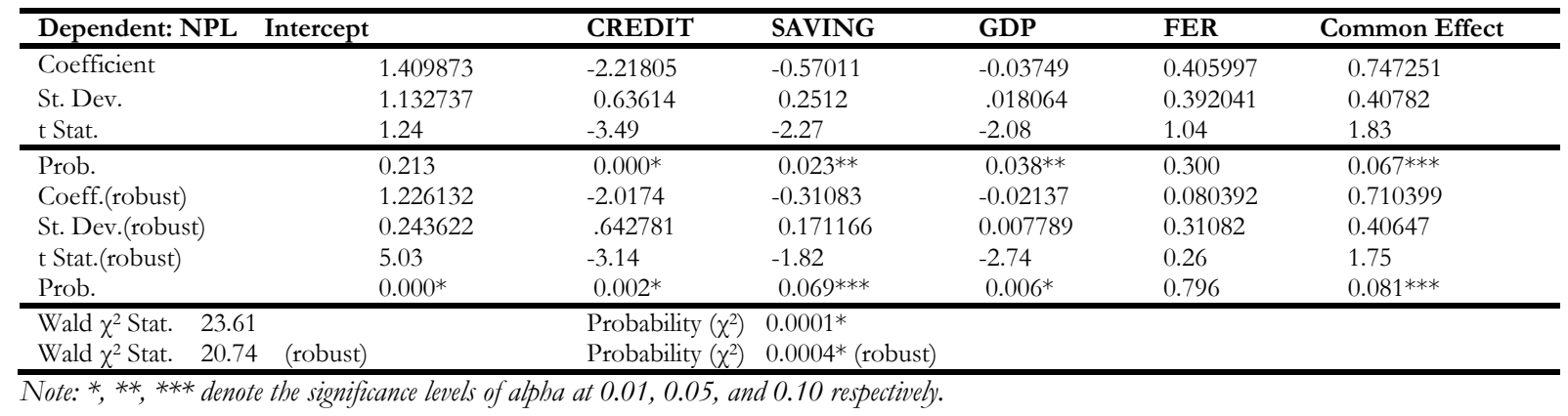

Table 8 shows the Eberhardt and Bond (2009) and Eberhardt and Teal (2010) Tests estimations of the panel regression model and both average and weighted (robust) estimation results are displayed for the overall panel. The results show that CREDIT, SAVING, and GDP variables have a statistically significant and negative effect on the dependent variable (NPL) at different significance levels throughout the panel. In this context, a $1 \%$ increase in CREDIT, SAVING, and GDP variables reduce NPL by approximately $2 \%, 0.3 \%$, and $0.02 \%$ respectively. FER variable has a positive coefficient, it has no statistically significant effect on NPL. According to the findings, we can accept that the model is statistically significant and presents reliable results.

Table 9. Panel Regression Model Estimation by Groups

\begin{tabular}{|c|c|c|c|c|c|}
\hline Countries & Intercept & CREDIT & SAVING & GDP & FER \\
\hline Argentina & $\begin{array}{l}.704224^{*} \\
5.40\end{array}$ & $\begin{array}{l}-0.88568 \\
-0.83\end{array}$ & $\begin{array}{l}-0.45836 \\
-0.37\end{array}$ & $\begin{array}{l}-0.02711 \\
-1.44\end{array}$ & $\begin{array}{l}-0.23462^{* *} \\
-1.88\end{array}$ \\
\hline Armenia & $\begin{array}{l}-7.56515 \\
-0.70\end{array}$ & $\begin{array}{l}0.488357 \\
0.21\end{array}$ & $\begin{array}{l}0.946186 \\
1.17\end{array}$ & $\begin{array}{l}-0.04147^{* * *} \\
-1.72\end{array}$ & $\begin{array}{l}1.546496 \\
0.89\end{array}$ \\
\hline Australia & $\begin{array}{l}0.256029 \\
0.23\end{array}$ & $\begin{array}{l}-7.71904 \\
-1.43\end{array}$ & $\begin{array}{l}-1.04202 \\
-0.45\end{array}$ & $\begin{array}{l}-0.0595 \\
-0.25\end{array}$ & $\begin{array}{l}-0.47306 \\
-0.31\end{array}$ \\
\hline Austria & $\begin{array}{l}.786363^{*} \\
6.34\end{array}$ & $\begin{array}{l}-2.9667 \\
-1.65\end{array}$ & $\begin{array}{l}0.405392 \\
0.31\end{array}$ & $\begin{array}{l}0.006048 \\
0.16\end{array}$ & $\begin{array}{l}0.414213 \\
1.25\end{array}$ \\
\hline Belgium & $\begin{array}{l}.006342^{*} \\
6.04\end{array}$ & $\begin{array}{l}1.099416 \\
0.77\end{array}$ & $\begin{array}{l}-1.01329 \\
-0.80\end{array}$ & $\begin{array}{l}-0.04413 \\
-1.03\end{array}$ & $\begin{array}{l}1.74713^{*} \\
2.90\end{array}$ \\
\hline Bosnia and Herzegovina & $\begin{array}{l}0.449434 \\
0.68\end{array}$ & $\begin{array}{l}-2.6303 \\
-1.51\end{array}$ & $\begin{array}{l}0.274923 \\
0.51\end{array}$ & $\begin{array}{l}0.053704 \\
0.98\end{array}$ & $\begin{array}{l}2.334539 \text { ** } \\
2.07\end{array}$ \\
\hline Brazil & $\begin{array}{l}2.156247^{*} \\
5.43\end{array}$ & $\begin{array}{l}-1.48315 \\
-1.18\end{array}$ & $\begin{array}{l}0.778036 \\
0.92\end{array}$ & $\begin{array}{l}-0.05898^{* * *} \\
-1.68\end{array}$ & $\begin{array}{l}-0.75607 * * \\
-2.38\end{array}$ \\
\hline Chile & $\begin{array}{l}0.30246 \\
0.04\end{array}$ & $\begin{array}{l}-3.73728 \\
-1.10\end{array}$ & $\begin{array}{l}-0.52547 \\
-0.20\end{array}$ & $\begin{array}{l}-0.02952 \\
-0.55\end{array}$ & $\begin{array}{l}0.035887 \\
0.03\end{array}$ \\
\hline Colombia & $\begin{array}{l}3.926058^{* *} \\
2.01\end{array}$ & $\begin{array}{l}0.394735 \\
0.70\end{array}$ & $\begin{array}{l}-0.62596 \\
-0.81\end{array}$ & $\begin{array}{l}-0.07579 * \\
-3.93\end{array}$ & $\begin{array}{l}-0.2959 \\
-1.21\end{array}$ \\
\hline Albania & $\begin{array}{l}0.704018 \\
0.32\end{array}$ & $\begin{array}{l}-4.81832 \\
-1.45\end{array}$ & $\begin{array}{l}-0.32165 \\
-0.46\end{array}$ & $\begin{array}{l}0.028991 \\
1.20\end{array}$ & $\begin{array}{l}0.600589 \\
0.49\end{array}$ \\
\hline Germany & $\begin{array}{l}0.179996 \\
1.00\end{array}$ & $\begin{array}{l}-3.69613 \\
-1.54\end{array}$ & $\begin{array}{l}-0.95741 \\
-0.45\end{array}$ & $\begin{array}{l}-0.02043 \\
-0.47\end{array}$ & $\begin{array}{l}-2.00786^{*} \\
-3.54\end{array}$ \\
\hline Honduras & $\begin{array}{l}6.021239 * \\
3.71\end{array}$ & $\begin{array}{l}-0.87477 \\
-1.01\end{array}$ & $\begin{array}{l}-0.13034 \\
-0.37\end{array}$ & $\begin{array}{l}-0.03633 \\
-1.29\end{array}$ & $\begin{array}{l}-1.55131 * \\
-2.98\end{array}$ \\
\hline Indonesia & $\begin{array}{l}20.97831 * \\
3.41\end{array}$ & $\begin{array}{l}-2.0689 \\
-1.28\end{array}$ & $\begin{array}{l}-0.41031 \\
-0.35\end{array}$ & $\begin{array}{l}-0.41967 * \\
-2.74\end{array}$ & $\begin{array}{l}-1.85801 * \\
-3.21\end{array}$ \\
\hline Ireland & $\begin{array}{l}2.5575^{*} \\
4.44\end{array}$ & $\begin{array}{l}-2.098 \\
-1.02\end{array}$ & $\begin{array}{l}0.703989 \\
0.54\end{array}$ & $\begin{array}{l}-0.06267^{* * *} \\
-1.69\end{array}$ & $\begin{array}{l}6.086312^{*} \\
3.00\end{array}$ \\
\hline Italy & $\begin{array}{l}2.370182 * \\
14.89\end{array}$ & $\begin{array}{l}-3.04523 * * \\
-2.31\end{array}$ & $\begin{array}{l}0.966068 \\
0.85\end{array}$ & $\begin{array}{l}0.013111 \\
0.50\end{array}$ & $\begin{array}{l}1.45106^{* *} \\
2.45\end{array}$ \\
\hline Madagascar & $\begin{array}{l}0.853014 \\
1.34\end{array}$ & $\begin{array}{l}-0.61193 * * \\
-2.20\end{array}$ & $\begin{array}{l}-0.15252 \\
-1.64\end{array}$ & $\begin{array}{l}0.030097 * \\
3.08\end{array}$ & $\begin{array}{l}0.113278 \\
1.39\end{array}$ \\
\hline Malta & $\begin{array}{l}0.775971 * \\
3.43\end{array}$ & $\begin{array}{l}-4.95023 \\
-1.42\end{array}$ & $\begin{array}{l}-0.28989 \\
-0.67\end{array}$ & $\begin{array}{l}0.001821 \\
0.07\end{array}$ & $\begin{array}{l}-2.96929 * * \\
-2.33\end{array}$ \\
\hline Mexico & $\begin{array}{l}1.683807^{*} \\
2.62\end{array}$ & $\begin{array}{l}-1.08025 \\
-0.95\end{array}$ & $\begin{array}{l}-1.2584 \\
-1.17\end{array}$ & $\begin{array}{l}-0.02722 \\
-1.51\end{array}$ & $\begin{array}{l}-0.28387 \\
-1.19\end{array}$ \\
\hline Northern Macedonia & $\begin{array}{l}0.335185 \\
0.26\end{array}$ & $\begin{array}{l}1.361541 * \\
2.73\end{array}$ & $\begin{array}{l}-0.52167 * * * \\
-1.66\end{array}$ & $\begin{array}{l}0.017398 \\
1.4\end{array}$ & $\begin{array}{l}0.298547 \\
0.94\end{array}$ \\
\hline Spain & $\begin{array}{l}1.256809^{*} \\
4.67\end{array}$ & $\begin{array}{l}-9.68649 * \\
-6.07\end{array}$ & $\begin{array}{l}-4.41579 * * * \\
-1.79\end{array}$ & $\begin{array}{l}-0.07894 * * \\
-2.52\end{array}$ & $\begin{array}{l}1.404536 \\
1.37\end{array}$ \\
\hline Thailand & $\begin{array}{l}-12.7335^{* * *} \\
-1.76\end{array}$ & $\begin{array}{l}4.276586^{*} \\
2.89\end{array}$ & $\begin{array}{l}-3.28902^{* * *} \\
-1.83\end{array}$ & $\begin{array}{l}-0.01275 \\
-0.40\end{array}$ & $\begin{array}{l}4.048188^{* *} \\
1.99\end{array}$ \\
\hline Turkey & $\begin{array}{l}1.137371 * \\
4.92\end{array}$ & $\begin{array}{l}1.004131 \\
0.87\end{array}$ & $\begin{array}{l}-1.65273 \\
-1.49\end{array}$ & $\begin{array}{l}-0.0248^{* *} \\
-1.98\end{array}$ & $\begin{array}{l}0.163114 \\
0.88\end{array}$ \\
\hline Ukraine & $\begin{array}{l}3.83702^{* * *} \\
1.77\end{array}$ & $\begin{array}{l}-3.05072 \\
-1.25\end{array}$ & $\begin{array}{l}-0.2568 \\
-0.29\end{array}$ & $\begin{array}{l}0.001913 \\
0.05\end{array}$ & $\begin{array}{l}-0.06998 \\
-0.10\end{array}$ \\
\hline
\end{tabular}


Note: ***, *** denote the significance levels of alpha at 0.01, 0.05, and 0.10 respectively.

Table 9 shows the results of AMG Estimator with Eberhardt and Bond (2009) and Eberhardt \& Teal (2010) for the panel regression model based on groups (countries). These results provide more appropriate information than the panel's overall estimate. Because the model represents heterogenous characteristics. Although the FER variable does not have a statistically significant effect throughout the panel, countries, where this variable is significant can be determined individually with this forecast. Although the coefficients differ quantitatively, according to AMG test results in Table 9, all coefficients were statistically insignificant for Austria, Australia, Albania, Chile, Mexico, and Ukraine. However, FER and NLP are positively correlated for Belgium, Bosnia and Herzegovina, Brazil, Indonesia, Ireland, Italy, and Thailand while FER and NLP are negatively correlated for Argentina, Germany, Honduras, and Malta. A negative correlation was found between GDP and NPL for Armenia, Colombia, Turkey, Brazil, Ireland, Spain, and Indonesia while the GDP coefficient is positive for Madagascar. Besides, there is a negative correlation between credit and NPL for Italy, Madagascar, and Spain. Although there is a positive correlation between credit and NPL for Northern Macedonia and Thailand. And there is a negative and statistically significant relationship between Saving and NPL in Northern Macedonia and Thailand. The relationship between the variables individually differ by the countries regarding to Eberhardt \& Bond (2009) and Eberhardt \& Teal (2010) AMG test results while the coefficients (negative) estimated for the other three explanatory variables that are significant throughout the panel.

\section{Discussion and Conclusion}

In this study, the main drivers of NPL in the selected 23 countries have been examined. In this context, yearly panel data between 2006 and 2018 is used. Also, 4 country-level macroeconomic indicators are considered to be used in the analysis by benefitting from the present literature. These variables are credits, FER, GDP, and savings. By considering the structure of data, heterogeneous panel analysis is performed.

As a result of the heterogeneous panel analysis, it is determined that 3 independent variables (i.e. credits, GDP, and savings) have a statistically important effect on NPL at the overall panel. In detail, a 1\% increase in credits, savings, and GDP reduces NPL by approximately $2 \%, 0.3 \%$, and $0.02 \%$ respectively. The connection and coefficients individually differs by countries regarding to Eberhardt \& Bond (2009) and Eberhardt \& Teal (2010) AMG test results. FER and NLP are positively correlated for Belgium, Bosnia and Herzegovina, Brazil, Indonesia, Ireland, Italy, and Thailand while FER and NLP are negatively correlated for Argentina, Germany, Honduras, and Malta. A negative correlation was found between GDP and NPL for Armenia, Colombia, Turkey, Brazil, Ireland, Spain, and Indonesia while the GDP coefficient is positive for Madagascar. Besides, there is a negative correlation between credit and NPL for Italy, Madagascar, and Spain. Although there is a positive correlation between credit and NPL for Northern Macedonia and Thailand. And there is a negative and statistically significant relationship between Saving and NPL in Northern Macedonia and Thailand.

These findings are consistent with the studies of Vithessonthi (2016, p. 295), K1liç Depren and Kartal (2020, p. 736) for credits; Messai and Jouini (2013, p.852); Skarica (2014, p. 37); Umar and Sun (2018, p. 273); Kilıç Depren and Kartal (2020, p. 736) for GDP growth. Also, FER don't have a statistically significant positive effect on NPL at the overall panel. Although various researchers like Jakubik and Reininger (2013, p. 48); Tanaskovic and Jandric (2015, p. 47); Umar and Sun (2018 p. 273); Kilıç Depren and Kartal (2020, p. 736) define that FER are influential on NPL, we have interestingly reached a different result at the overall panel.

On the other hand, it is defined that FER have statistically significant negative effects in Argentina, Brazil, Germany, Honduras, Indonesia, and Malta while having statistically significant positive effects Belgium, Bosnia-Herzegovina, Ireland, Italy, and Thailand at the country base. Moreover, negative coefficients for credits, savings, and GDP are consistent in both the overall panel and country base.

The findings of the study mainly reveal that the effects and importance of country-level macroeconomics indicators have a quite high and significant effect on NPL. By considering this finding, countries should focus on influential factors that are effective. Therefore, each country analyzed in the study should give priority to the most important variable firstly, and could deal with other factors (i.e. savings and GDP) after that. In this context, the main priorities of countries are the credits, savings, and GDP, respectively. Because effective factors (i.e. credits, GDP, and savings) are national factors, they are mostly under the control of countries. For this reason, each country should try to stimulate the positive 
contributions of these indicators on NPL. Hence, countries can benefit from decreasing NPL by providing more credits to their economies. After achieving success in using the positive effect of the influential variables, countries could also focus on other factors in turn. In total, any measures related to increasing the efficiency of banks, expanding the liquidity and competition in the financial markets could be beneficial in providing a positive contribution to the variables considered in the study and NPL in turn. In this context, it is evaluated that taking measures by considering the results of the study could help countries to decrease NPL. By applying this, negative developments on NPL could be prevented and banks could provide much more financing to economic actors, economic growth, and the development of countries as well.

The results of the analysis emphasize the effects of macroeconomic determinants on NPL. In particular, the results of this study show the importance of credits in terms of the development of NPL. Therefore, the most significant inferences of the analysis for beneficiaries (especially regulator, supervisor and the managers of the banking systems and banks in countries) are that they should consider the credit quality, collateral quality and the characteristics of borrowers in credit allocation process so that they could provide credit growth in a healthy way. Besides, increasing savings, by considering they could be used for the payment of NPL in bad days, is an important inference for economy management of countries. A similar case is valid for GDP growth as well. When economies are growing (i.e. GDP growth is positive), then borrowers could repay their credit, increase their savings for bad days. Moreover, any development in indicators either used or unused in this study should be strictly followed up in terms of their effects on NPL before they cause negative developments. Hence, countries could have the capacity in managing NPL effectively.

Also, as an important point, it should be stated that authorities should give more attention to NPL. In other words, the economic management of countries should NPL as a macro-prudential issue. Besides, monetary and fiscal policies should be applied in a harmonious way since they may have a high capacity to effect NPL.

In this study, we examine 23 selected countries by considering data availability. However, there are still a variety of countries that could be examined in terms of NPL. Also, using solely country-level macroeconomic indicators is a limitation for this study. Considering these limitations, new studies could make an additional contribution to the literature in the future. Also, the different bundles of developed and emerging countries could be examined in the same study. Also, a study for countries, which have quite high NPL such as San Marino, Greece, Ukraine, Albina, United Arab Emirates, Nigeria, Argentina, may be prepared by researchers. Moreover, new variables such as volatility, crude oil, and commodity prices that are not covered in the study could be included and new statistical econometric methods could be applied in the forthcoming studies.

\section{Ethical Declaration}

In the writing process of the study titled "The Macro Economic Drivers of Non-Performing Loans (NPL): Evidence from Selected Countries with Heterogeneous Panel Analysis", there were followed the scientific, ethical and the citation rules; was not made any falsification on the collected data and this study was not sent to any other academic media for evaluation. Since the data set is used in this article, ethics committee approval is not required.

\section{References}

Alandejani, M., \& Asutay, M. (2017). Nonperforming loans in the GCC banking sectors: does the islamic finance matter? Research in International Business and Finance, 42, 832-854. do1: 10.1016/j.ribaf.2017.07.020

Baltagi, B. (2008). Econometric analysis of panel data (4th ed.). Hoboken, NJ: John Wiley \& Sons.

Baltagi, B. H., Feng, Q., \& Kao, C. (2012). A lagrange multiplier test for cross-sectional dependence in a fixed effects panel data model. Journal of Econometrics, 170(1), 164-177. doi: https://doi.org/10.1016/j.jeconom.2012.04.004

Barseghyan, L. (2010). Non-Performing loans, prospective bailouts, and Japan's slowdown. Journal of Monetary Economics, 57(7), 873-890. https://doi.org/10.1016/j.jmoneco.2010.08.002

Beck, R., Jakubik, P., \& Piloui, A. (2013). Non-Performing loans what matters in addition to the economic CYCLE? ECB Working Paper, No. 1515. Frankfurt am Main, Germany: European Central Bank. ISSN 1725-2806 (online)

Breusch, T., \& Pagan, A. (1980). The Lagrange Multiplier Test and Its Applications to Model Specification in Econometrics. Review of Economic Studies, 47(1), 239-253.

Bilgin, M. H., Gözgör, G., Lau, C. K. M., and Sheng, X. (2018). The effects of uncertainty measures on the price of gold. International Review of Financial Analysis, 58, 1-7. Doi: https://doi.org/10.1016/j.irfa.2018.03.009 
Boudriga, A., Taktak, N. B., \& Jellouli, S. (2010). Bank specific, business and institutional environment determinants of banks nonperforming loans: Evidence from MENA countries. Economic Research Forum Working Paper $\mathrm{Nu}: 547$.

Buncic, D., \& Melecky, M. (2013). Macroprudential stress testing of credit risk: A practical approach for policy makers. Journal of Financial Stability, 9(3), 347-370. Doi: https://doi.org/10.1016/j.jfs.2012.11.003

Das, A., \& Ghosh, S. (2007). Determinants of credit risk in Indian state-owned banks: An empirical investigation. Munich Personal RePEc Archive, MPRA Paper No. 17301. Online at https://mpra.ub.unimuenchen.de/17301/

De Bock, R., \& Demyanets, A. (2012). Bank asset quality in emerging markets: determinants and spillovers. IMF Working Paper, No. 12/71.

Dimitrios, A., Helen, L., \& Mike, T. (2016). Determinants of non-performing loans: evidence from euro-area countries. Finance Research Letters, (18), 116-119. Doi: https://doi.org/10.1016/j.frl.2016.04.008

Distinguin, I., Roulet, C., \& Tarazi, A. (2013). Bank regulatory capital and liquidity: evidence from US and European publicly traded banks. Journal of Banking and Finance, 37(9), 3295-3317. Doi: https://doi.org/10.1016/j.jbankfin.2013.04.027

Eberhardt, M., \& Bond, S. (2009). Cross-section dependence in nonstationary panel models: A novel estimator. Munich Personal RePEc Archive, MPRA Working Paper, No. 17870. Online at https://mpra.ub.unimuenchen.de/17870/

Eberhardt, M., \& Teal, F. (2010). Productivity analysis in global manufacturing production. University Discussion Paper Series of Oxford Working Paper, No. 515.

Erdaş, M. L. (2009). Do macroeconomic variables have a symmetric or asymmetric effect on non-performing loans? Evidence from Turkey. Journal of Mehmet Akif Ersoy University Faculty of Economics and Administrative Sciences, 6(2), 370-392. Doi: https://doi.org/10.30798/makuiibf.518076

Espinoza, R. A., \& Prasad, A. (2010). Nonperforming loans in the GCC banking system and their macroeconomic effects. IMF Working Paper, No: 10/224.

Farhan, M., Sattar, A., Chaudhry, A. H., \& Khalil, F. (2012). Economic determinants of non-performing loans: perception of Pakistani bankers. European Journal of Business and Management, 4(19), 87-99.

Ghosh, A. (2015). Banking-industry specific and regional economic determinants of non-performing loans: evidence from US states. Journal of Financial Stability, 20, 93-104. Doi: https://doi.org/10.1016/j.jfs.2015.08.004

Gözgör, G., Demir, E., Belás, J., \& Yeşilyurt, S. (2019). Does economic uncertainty affect domestic credits? an empirical investigation. Journal of International Financial Markets, Institutions and Money, 63, 1-11. Doi: https://doi.org/10.1016/j.intfin.2019.101147

Jakubik, P., \& Reininger, T. (2013). Determinants of nonperforming loans in central, eastern and southeastern europe, focus on european economic integration. Oesterreichische Nationalbank. (Austrian Central Bank), 3, 48-66.

Kartal, M. T., Ibiş, C., \& Çatıkkaş, Ö. (2018). Adequacy of audit committees: a study of deposit banks in Turkey. Borsa Istanbul Review, 18(2), 150-165. Doi: https://doi.org/10.1016/j.bir.2018.01.002

Kaufmann, S., \& Valderrama, M. T. (2008). Bank lending in Germany and the UK: are there differences between a bank-based and a market-based country?, International Journal of Finance and Economics, 13(3), 266-279. Doi: https://doi.org/10.1002/ijfe.345

Kılıç Depren, S., \& Kartal, M. T. (2020). Prediction on the volume of non-performing loans (NPL) in Turkey using multivariate adaptive regression splines (MARS) approach. International Journal of Finance and Economics, In Press. Doi: https://doi.org/10.1002/ijfe.2126

Klein, N. (2013). Non-Performing loans in CESEE: determinants and impact on macroeconomic performance. IMF Working Paper, No. 13/72.

Konstantakis, K. N., Michaelides, P. G., \& Vouldis, A. T. (2016). Non-Performing loans (NPLs) in a crisis economy: long-run equilibrium analysis with a real time VEC model for Greece (2001-2015). Physica A: Statistical Mechanics and Its Applications, 451, 149-161. Doi: https://doi.org/10.1016/j.physa.2015.12.163

Louzis, D. P., Vouldis, A. T., \& Metaxas, V. L. (2012). Macroeconomic and bank-specific determinants of nonperforming loans in Greece: a comparative study of mortgage, business and consumer loan portfolios. Journal of Banking and Finance, 36(4), 1012-1027. Doi: https://doi.org/10.1016/j.jbankfin.2011.10.012

Maddala, G.S., Trost, R.P., Li, H., \& Joutz, F. (1997). Estimation of short-run and long-run elasticities of energy demand from panel data using shrinkage estimators. Journal of Business and Economic Statistics, 15(1), 90-100.

Messai, A. S., \& Jouini, F. (2013). Micro and macro determinants of non-performing loans. International Journal of Economics and Financial Issues, 3(4), 852-860.

Mohammad, S., Asutay, M., Dixon, R., \& Platonova, E. (2020). Liquidity risk exposure and its determinants in the banking sector: a comparative analysis between islamic, conventional and hybrid banks. Journal of International Financial Markets, Institutions and Money, 66, 1-20. https://doi.org/10.1016/j.intfin.2020.101196

Morgan, P. J., \& Pontines, V. (2018). Financial stability and financial inclusion: the case of SME lending. The Singapore Economic Review, 63(1), 111-124.

Nkusu, M. (2011). Non-performing loans and macrofinancial vulnerabilities in advanced economies. IMF Working Paper, No. 11/161.

Pesaran, M. H., \& Smith, R. (1995). Estimating long-run relationships from dynamic heterogeneous panels. Journal of Econometrics, 68(1), 79-113. Doi: https://doi.org/10.1016/0304-4076(94)01644-F 
Pesaran, M. H. (2004). General diagnostic tests for cross section dependence in panels. University of Cambridge, Faculty of Economics. Cambridge Working Paper, No. 0435.

Pesaran, M. H. (2007). A simple panel unit root test in the presence of cross sectional dependence. Journal of Applied Econometrics, 22(2), 265-312. https://doi.org/10.1002/jae.951

Pesaran, M. H., \& Yamagata, T. (2008). Testing slope homogeneity in large panels. Journal of Econometrics, 142(1), 5093. Doi: https://doi.org/10.1016/j.jeconom.2007.05.010

Saba, I., Kouser, R., \& Azeem, M. (2012). Determinants of non-performing loans: case of US banking sector. The Romanian Economic Journal, 44(6), 125-136.

Salas, V., \& Saurina, J. (2002). Credit risk in two institutional regimes: spanish commercial and savings banks. Journal of Financial Services Research, 22(3), 203-224.

Saunders, A., \& Cornett, M. (2006). Financial institutions management: a risk management approach. (Fifth Edition). Boston: McGraw-Hill.

Skarica, B. (2014). Determinants of non-performing loans in central and eastern european countries. Financial Theory and Practice, 38(1), 37-59.

Swamy, P. (1970). Efficient inference in a random coefficient regression model. Econometrica, 38(2), 311-322.

Tanaskovic, S., \& Jandric, M. (2015). Macroeconomic and institutional determinants of non-performing loans. Journal of Central Banking Theory and Practice, 4(1), 47-62.

Touny, M. A., \& Shehab, M. A. (2015). Macroeconomic determinants of non-performing loans: an empirical study of some arab countries. American Journal of Economics and Business Administration, 7(1), 11-22. DOI: 10.3844/ajebasp.2015.11.22

Umar, M., \& Sun, G. (2018). Determinants of non-performing loans in chinese banks. Journal of Asia Business Studies, 12(3), 273-289. DOI 10.1108/JABS-01-2016-0005

Vithessonthi, C. (2016). Deflation, bank credit growth, and non-performing loans: evidence from japan. International Review of Financial Analysis, (45), 295-305. Doi : https://doi.org/10.1016/j.irfa.2016.04.003

WB (2020). Open Data, https:/ / data.worldbank.org/indicator, 06.30.2020.

Zeng, S. (2012). Bank non-performing loans (npls): a dynamic model and analysis in china. Modern Economy, (3), 100110. Doi: http://dx.doi.org/10.4236/me.2012.31014 P

Annex 1. NPL Ratios for Selected Countries

\begin{tabular}{|c|c|c|c|c|c|c|c|c|c|c|c|c|c|}
\hline $\begin{array}{l}\stackrel{D}{E} \\
0 \\
0\end{array}$ & 2006 & 2007 & 2008 & 2009 & 2010 & 2011 & 2012 & 2013 & 2014 & 2015 & 2016 & 2017 & 2018 \\
\hline$\overline{\mathrm{ARG}}$ & 4,46 & 3,24 & 3,11 & 3,47 & 2,12 & 1,40 & 1,73 & 1,73 & 1,99 & 1,74 & 1,84 & 1,83 & 3,11 \\
\hline ARM & 2,45 & 2,40 & 4,28 & 4,86 & 3,04 & 3,42 & 3,67 & 4,49 & 6,97 & 7,95 & 6,72 & 5,43 & 4,75 \\
\hline AUS & 0,57 & 0,56 & 1,36 & 2,02 & 2,15 & 1,97 & 1,75 & 1,40 & 1,05 & 0,92 & 0,98 & 0,89 & 0,93 \\
\hline AUT & 2,74 & 2,24 & 1,90 & 2,25 & 2,83 & 2,71 & 2,81 & 2,87 & 3,47 & 3,39 & 2,70 & 2,37 & 1,88 \\
\hline BEL & 1,28 & 1,16 & 1,65 & 3,08 & 2,80 & 3,30 & 3,74 & 4,24 & 4,18 & 3,79 & 3,43 & 2,92 & 2,27 \\
\hline $\mathrm{BIH}$ & 4,00 & 3,02 & 3,09 & 5,87 & 11,42 & 11,80 & 13,47 & 15,12 & 14,17 & 13,71 & 11,78 & 10,05 & 8,77 \\
\hline BRA & 3,46 & 2,98 & 3,11 & 4,21 & 3,11 & 3,47 & 3,45 & 2,86 & 2,85 & 3,31 & 3,92 & 3,59 & 3,05 \\
\hline CHL & 0,75 & 0,75 & 0,98 & 2,93 & 2,69 & 2,35 & 2,16 & 2,11 & 2,06 & 1,87 & 1,83 & 1,92 & 1,87 \\
\hline COL & 2,66 & 3,23 & 3,93 & 4,01 & 2,86 & 2,50 & 2,76 & 2,77 & 2,92 & 2,85 & 3,12 & 4,18 & 4,40 \\
\hline HRV & 5,19 & 4,75 & 4,87 & 7,66 & 11,09 & 12,27 & 13,76 & 15,43 & 16,71 & 16,33 & 13,61 & 11,20 & 9,71 \\
\hline DEU & 3,41 & 2,65 & 2,85 & 3,31 & 3,20 & 3,03 & 2,86 & 2,70 & 2,34 & 1,97 & 1,71 & 1,50 & 1,24 \\
\hline HND & 3,95 & 3,06 & 4,34 & 4,74 & 3,66 & 2,94 & 3,29 & 3,39 & 3,27 & 3,06 & 2,92 & 2,36 & 2,15 \\
\hline IDN & 5,89 & 4,00 & 3,19 & 3,29 & 2,53 & 2,14 & 1,77 & 1,69 & 2,07 & 2,43 & 2,90 & 2,56 & 2,29 \\
\hline IRL & 0,53 & 0,63 & 1,92 & 9,80 & 13,05 & 16,12 & 24,99 & 25,71 & 20,65 & 14,93 & 13,61 & 11,46 & 5,73 \\
\hline ITA & 6,57 & 5,78 & 6,28 & 9,45 & 10,03 & 11,74 & 13,75 & 16,54 & 18,03 & 18,06 & 17,12 & 14,38 & 8,39 \\
\hline MDG & 6,15 & 6,70 & 6,40 & 8,10 & 9,62 & 10,69 & 11,13 & 11,63 & 10,12 & 9,01 & 8,36 & 7,67 & 7,20 \\
\hline MLT & 6,47 & 5,31 & 5,01 & 5,78 & 7,02 & 7,09 & 7,75 & 8,95 & 8,83 & 7,10 & 5,29 & 4,07 & 3,36 \\
\hline MEX & 1,78 & 2,35 & 2,97 & 2,81 & 2,04 & 2,12 & 2,44 & 3,24 & 3,04 & 2,52 & 2,09 & 2,09 & 2,05 \\
\hline MKD & 11,21 & 7,51 & 6,71 & 8,94 & 9,04 & 9,52 & 10,11 & 10,94 & 10,81 & 10,31 & 6,29 & 6,10 & 5,04 \\
\hline ESP & 0,70 & 0,90 & 2,81 & 4,12 & 4,67 & 6,01 & 7,48 & 9,38 & 8,45 & 6,16 & 5,64 & 4,46 & 3,69 \\
\hline THA & 7,77 & 7,60 & 5,60 & 5,22 & 3,89 & 2,93 & 2,43 & 2,30 & 2,31 & 2,68 & 2,99 & 3,07 & 3,08 \\
\hline TUR & 3,58 & 3,32 & 3,44 & 4,97 & 3,49 & 2,58 & 2,74 & 2,64 & 2,74 & 2,99 & 3,11 & 2,84 & 3,69 \\
\hline UKR & 59,76 & 48,12 & 3,88 & 13,70 & 15,27 & 14,73 & 16,54 & 12,89 & 18,98 & 28,03 & 30,47 & 54,54 & 52,85 \\
\hline
\end{tabular}




\section{TÜRKÇE GENİ̧̧ ÖZET}

Finansal sistemler temelde banka bazlı veya piyasa bazlı olmak üzere iki gruba ayrılmaktadır (Kartal, İbiş ve Çatıkkaş, 2018). Finansal sistemin türü kilit bir role sahiptir çünkü altyapı ve finansal kurumlar buna göre tasarlanmıştır. Ayrıca bu sistemlerdeki finansal aracılar, ekonomik faaliyetler para ve kredi kanalları kullanılarak finans kurumları tarafından finanse edildiğinden ülkelerin kalkınmasında önemli bir role sahiptir. Ülke ekonomileri incelendiğinde, genel olarak banka bazlı finansal sistemlere sahip oldukları görülmektedir.

Bankalar, finansal sistemlerde ana finansal aracılardır. Öncelikle bankalar nakit fazlası olan ve biriktirmek isteyenlerden mevduat toplar. İkincisi, bankalar, yatırım ve tüketim gibi ekonomik faaliyetleri gerçekleştirmek için borçlanmaya ihtiyaç duydukları kredileri sağlarlar. Bu nedenle, bankalar uzun vadeli varlıkları ve kısa vadeli borçları yönetir, vadeleri dönüştürür ve riskli varlıklarını (NPL-takipteki krediler gibi likit olmayan varlıklar dahil) finanse eder.

Büyük miktarda kredi sağlayan finans kuruluşları olarak, kredilerin geri dönüşleri (geri ödemeleri) bankaların sürdürülebilirliği açısından hayati önem taşımaktadır. Bu noktada ana sorun NPL'dir. NPL, genel olarak vadesi geçen olumsuz krediler olarak tanımlanabilir. NPL arttıkça bankaların kredi tahsis kapasitesi, karlllığı ve likiditesi azalır, tersi de geçerlidir. Ayrıca NPL, bankaların ve bankacıllk sektörünün sağlamlığını yansıtan temel göstergeler arasında yer almaktadır (Touny ve Shehab, 2015, s.11). Bu nedenle, banka yönetimi kredi büyümesini sürdürmek için düşük düzeyde NPL'ye sahip olmayı arzularken, ekonomi yönetimi de kredi büyümesi yoluyla ekonomik büyümeyi canlandırmak istemektedir (Barseghyan, 2010, s.874). Banka tabanlı finansal sistemleri olan ülkeler, ekonomik faaliyetleri canlandırmak için bankacılık ile ilgili konulara odaklanmalıdır (Kaufmann ve Valderrama, 2008, s. 267).

Bankacılık sektörlerinin istikrarı ve sağlamlığ1, özellikle gelişmekte olan ülkelerin ekonomik büyümesi için önem arz etmektedir. Bu amaçla makroekonomik ve finansal göstergelerde istikrarın sağlanması ve sürdürülmesi temel ihtiyaçlardan biridir. Makroekonomik ve finansal göstergeler, küresel ve ulusal dahil olmak üzere çeşitli göstergelerden etkilenmektedir. Ulusal göstergeler (örn. Krediler, tasarruflar, GSYİH) tamamen veya çoğunlukla ülkelerin kontrolü altındayken, ne yazık ki küresel faktörler (örn. Döviz kuru) ülkelerin kontrolü altında değildir. Yine de ülkeler küresel faktörlerin etkilerini etkileyebilir ve yönlendirebilmektedir.

NPL, belirsizliğe neden olarak kredi büyümesini, ekonomik büyümeyi ve döviz kuru, enflasyon ve işsizlik gibi diğerlerini etkileyen ülkelerin gelişimini etkileyebilir. NPL'deki ani artışlar sırasıyla olumsuz etkilere, yüksek miktarda iflaslara, yeni kredi tahsislerinde azalmaya ve dolayısıyla ekonomilerde yıkıc1 gelişmelere neden olabilir. Dolayısıyla takibe dönüşüm miktarı ve seviyesi gelişme ve büyüme patikasından farklılaşmaktadır (Bilgin, Gözgör, Lau ve Sheng, 2018, s. 2; Gözgör, Demir, Belás ve Yeşilyurt, 2019, s. 2).

Piyasaya dayalı finansal sistemler çoğunlukla gelişmiş ülkelerde ön plana çıkarken, gelişmekte olan ülkelerin finansal sistemleri ağırlıklı olarak bankalara dayanmaktadır. Krediler, bu tür ülkelerde temel ve en önemli finansal araçlardır. Bu nedenle, düşük miktar ve düzeyde NPL sağlanarak kredi büyümesinin sürdürülebilirliği oldukça kritiktir. Kredi büyümesi daha çok bankaların ve bankacıllk sektörünün sağlamlı̆g1 ve finansal istikrarı ile ilgilidir ve kredilerdeki bozulmalar NPL olarak görülmektedir. Ayrıca, krediler, takipteki alacaklar ve makroekonomik ve finansal göstergeler arasında derin bir ilisski mevcuttur. Banka kaynaklı ekonomilerde bozulmalar arttığında, NPL de aynı zamanda artmaktadır.

Çalışma, en güncel veriler kullanılarak seçilmiş ülkelerdeki NPL'nin belirleyicilerini inceleyerek literatüre katkıda bulunmayı amaçlamaktadır. Verilerine ulaşılabilen 23 ülke seçilmiş ülke üzerinde uygulamalı analiz yapılmıştır. Bu bağlamda, seçilen ülkelerdeki NPL'sinin itici güçlerini tanımlamak için çalş̧mada 4 ana bağımsız değişken olarak özel sektöre verilen yurtiçi kredi (\% GSMH), resmi döviz kuru, yıllık GSMH artışı ve brüt tasarruflar kullanılmıştır. Çalışmada 2006-2018 dönemine ait yıllık veriler kullanılarak ve heterojen panel analizi yapılmıştır. Ayrıca, çalışma kredilerin, GSYIH'nın ve tasarrufların istatistiksel olarak anlamlı bir olumsuz etkiye sahip olduğunu, buna karşın döviz kurunun genel panel için NPL üzerinde istatistiksel olarak anlamlı olmayan pozitif etkiye sahip olduğunu tanımlamaktadır. Ayrıca, bazı ülkelerde döviz kurunun istatistiksel olarak anlamlı negatif ve pozitif etkilere sahip olduğu da belirlenmiştir. Ayrıca, krediler, tasarruflar ve GSYİH değişkenleri için negatif katsayılar hem genel panelde hem de ülke bazında tutarlıdır. Sonuçlar makroekonomik belirleyicilerin NPL üzerindeki önemini kanitlamaktadir. 
Heterojen panel analizi sonucunda, 3 bağımsız değişkenin (krediler, GSYİH ve tasarruflar) genel panelde NPL üzerinde istatistiksel olarak önemli bir etkiye sahip olduğu belirlenmiştir. Krediler, tasarruflar ve GSYİH'daki $\%$ 1'lik bir artış, takipteki kredileri sırasıyla yaklaşık $\% 2, \% 0,3$ ve $\% 0,02$ oranında azaltmaktadır. Bu bulgular krediler için; Vithessonthi (2016, s. 295), Kılıç Depren ve Kartal'ın (2020, s. 736) bulgular1 ile GSYIH büyümesi için ise Messai VE Jouini (2013, s. 852); Skarica (2014, s. 37); Umar ve Sun (2018, s. 273); Kılıç Depren ve Kartal'ın (2020, s. 736) bulguları ile uyumludur. Ayrıca, döviz kurunun genel panelde NPL üzerinde istatistiksel olarak anlamlı bir pozitif etkisi olmadığı tespit edilmiştir. Jakubik ve Reininger (2013, s. 48); Tanaskovic ve Jandric (2015, s. 47); Umar ve Sun (2018 s. 273); Killç Depren ve Kartal (2020, s. 736) gibi çeşitli araştırmacılar döviz kurunun NPL üzerinde etkili olduğunu bulmuş olmalarına rağmen, bu çalışmanın bulguları ile örtüşmemektedir.

Öte yandan döviz kuru değişkeni ülke bazında incelendiğinde Arjantin, Brezilya, Almanya, Honduras, Endonezya ve Malta'da istatistiksel olarak anlamlı olumsuz etkiye sahip iken; Belçika, Bosna-Hersek, İlanda, İtalya ve Tayland'da istatistiksel olarak anlamlı olumlu etkiye sahip olduğu belirlenmiştir. Ayrıca, krediler, tasarruflar ve GSYİH için negatif katsayılar hem genel panelde hem de ülke bazında tutarlı sonuç ortaya koymuştur.

Çalışmanın bulguları, temel olarak ülke düzeyindeki makroekonomik göstergelerin etkilerinin ve öneminin NPL üzerinde oldukça yüksek ve anlamlı bir etkiye sahip olduğunu ortaya koymaktadır. Bu bulguyu dikkate alarak, ülkeler etkili olan etkili faktörlere odaklanmalıdır. Bu nedenle, çalışmada analiz edilen her ülke öncelikle en önemli değişkene öncelik vermeli ve bundan sonra diğer faktörlerle (yani tasarruflar ve GSYİH) ilgilenebilir. Bu bağlamda, ülkelerin ana öncelikleri sırasıyla kredi, tasarruf ve GSYİH'dir. Etkili faktörler (yani krediler, GSYİH ve tasarruflar) ulusal faktörler olduğundan, çoğunlukla ülkelerin kontrolü altındadırlar. Bu nedenle her ülke bu göstergelerin NPL'ye olumlu katkılarını teşvik etmeye çalışmalıdır. Böylelikle ülkeler, ekonomilerine daha fazla kredi sağlayarak NPL'nin düşmesinden faydalanabilirler. Etkili değişkenlerin olumlu etkisini kullanarak başarıya ulaştıktan sonra, ülkeler sırayla diğer faktörlere de odaklanabilir. Toplamda, bankaların etkinliğinin artırılması, likiditenin genișletilmesi ve finansal piyasalarda rekabet ile ilgili her türlü önlem, çalışmada ele alınan değişkenlere ve buna bağlı olarak takipteki alacaklara olumlu katkı sağlamada faydalı olabilir. Bu bağlamda, araştırma sonuçları dikkate alınarak önlem almanın ülkelere NPL'nin azaltılmasına yardımcı olabileceği değerlendirilmektedir. Bu uygulama ile NPL üzerindeki olumsuz gelişmeler önlenebilir ve bankalar ekonomik aktörlere, ekonomik büyümeye ve ülkelerin kalkınmasına da çok daha fazla finansman sağlayabilir. 